\title{
TUJPED
}

Turkish Journal of Primary Education

Turkish Journal of Primary Education, 2021, 6 (1), 36-50

\section{Özel Eğitim Bölümü Lisans Programlarının Birleştirilmesine Yönelik Özel Ĕ̆itim Öğretmenlerinin Görüşlerinin Değerlendirilmesi}

\author{
Gözdenur AYDIN ${ }^{1} \&$ Şener ŞENTÜRK ${ }^{2}$ \\ ${ }^{1}$ Ondokuz Mayls Üniversitesi, ${ }^{2}$ Ondokuz Mayls Üniversitesi
}

\section{$\ddot{O} z e t$}

Bu araştırmanın amacı, özel ĕgitim öğretmenlerinin mezun oldukları eski lisans programlarının eksiklerinin neler olduğu yönündeki görüşlerinin belirlenmesi ve bu görüşler üzerinden 2016-2017 Özel Ĕ̈itim Öğretmenliği Lisans Programının neleri karşılayıp karşılamadiğının saptanmasıdır. Nitel araştırma yöntemi ile gerçekleştirilen çalışmanın veri analizi içerik analizi ile gerçekleştirilmiştir. Geçerlik ve güvenirliğin sağlanması için katılımcı teyidine başvurulmuş ve katılımcı görüşlerine araştırmada doğrudan yer verilmiştir. Araştırmanın katılımcı kitlesi farkl üniversitelerden mezun ve Türkiye’nin farklı bölgelerinde görev yapmakta olan 53 özel ĕgitim ögretmeninden oluşmaktadır. Araştırmaya katılan ögretmenlerin \%67'si resmî kurumlarda, \%33'ü özel kurumlarda çalışmaktadır. Katılımcıların \%45'i zihin engelliler ögretmenliği, \%51'i işitme engelliler ögretmenliği, \%4’ü görme engelliler öğretmenliği mezunudur. Yarı yapılandırılmış görüşme formunun kullanıldığı araştırmada veriler, belirli temalar altında gruplandırılarak yorumlanmıştır. Araştırma bulgularına göre eski lisans programlarının niteliğine yönelik uygulama derslerinin verimsiz olması; müfredatın, akademik kadronun yetersizliği ve niteliksizliği; programın mesleki becerileri karşılayamaması gibi sonuçlara ulaşılmıştır. Incelenen 2016-2017 Özel Ĕ̈itim Lisans Programı ve alınan öğretmen görüşleri neticesinde birleştirilen programın teoride ihtiyacı karşılayacă̆ı görüşüne varılmıştır.

Anahtar kelimeler: Özel ĕ̆itim, ögretmen yetiştirme programı, ögretmen görüşü

\section{Special Education Teachers' Views on the Unification of the Special Education Department Undergraduate Programs}

\begin{abstract}
The aim of this study is to determine the opinions of special education teachers about the deficiencies of the former undergraduate programs they graduated from, and also to determine what the 2016-2017 Special Education Teaching Undergraduate Program meets or not through these opinions. The data analysis of the study, which was carried out with the qualitative research method, was carried out with content analysis. In order to ensure validity and reliability, participant confirmation was used and participant views were directly included in the study. The audience in the research consists of 53 teachers who graduated from different universities and working in different regions of Turkey. $67 \%$ of the teachers participating in the research work in public institutions and $33 \%$ in private institutions. $45 \%$ of the participants were graduates of teachers for the mentally handicapped, $51 \%$ of teachers for the hearing impaired, and $4 \%$ of teachers for the visually impaired. In the study in which the semi-structured interview form was used, the data were grouped under certain themes and interpreted. According to the research findings, the application courses for the quality of the old undergraduate programs are inefficient; inadequacy of the curriculum and academic staff and It was concluded that the program could not meet the professional skills. As a result of the examined 2016-2017 Special Education Undergraduate Program and the teachers' opinions, it was concluded that the combined program would meet the need in theory.
\end{abstract}

Keywords: Special education, teacher training program, teacher opinion

Sorumlu yazar e-mail: gozdenuraydin0@gmail.com

Orcid No: 0000-0002-1627-3981

DOI: $10.52797 /$ tujped.829099 


\section{GİRIŞ}

Her çocuk ayrı bir dünyadır ve her biri ayrı dünyaların çocuklarıdır. Bu nedenle zihinsel, sosyal, duygusal gelişimleri öğrenme hızları, öğrenme stilleri bir birinden farklılık gösterir. Bu farklılıklar özel gereksinimli çocuklarda daha da yoğundur. Öyle ki onların kendilerine özgü yeteneklerini geliştirmek için ya okul uygulamalarında değişikliğe gidilmesine ya da özel eğitim hizmetlerine ihtiyaç duyarlar (Kirk, Gallagher \& Coleman, 2017). Bu kapsamda özel eğitim, çoğunluktan farklı özelliklere sahip olan bireylerin desteklenmesi ve onların sahip olduğu yeteneklerin en üst düzeye çıkabilmesi için çaba gösterilen bir eğitim sistemi olarak tanımlanmaktadır. Bu eğitim aynı zamanda kişinin kendi kendine yetebilmesine, toplumla iç içe olmasına ve başta kendi sonra da toplum için faydalı bir birey haline gelebilmesi için verilen eğitim olarak da nitelendirilebilir (Ataman, 2013). Literatürde yer alan özel eğitim tanımları incelendiğinde genel bağlamda "norm dışı bireylere sunulan hizmet" olarak tanımlanmaktadır. Sezgin'e (2013) göre normalin tanımı, normalin ölçüsü ve normalin çeşitlilikleri alanyazında kavramsal boyutta da tartışılmaya devam eden bir konudur. Bu doğrultuda özel eğitimin sadece "norm dışı bireylere sunulan eğitim" gibi kısır bir tanımla sınırlı kalmaması gerektiği, yetersizlikten etkilenmiş bireyleri her yönüyle hayata dâhil etmeyi hedefleyen ve muhatabi olduğu çevrenin de bu eğitim sürecine dâhil edilmesi gereken bir sistem olduğu söylenebilir.

Özel Eğitim Hizmetleri Yönetmeliği’nde özel eğitim, bireysel ve gelişim özellikleri ile eğitim yeterlilikleri açısından akranlarından anlamlı düzeyde farklılaşan kişilerin, eğitim ve sosyal ihtiyaçlarını karşılamak üzere geliştirilmiş eğitim programı ve özel yetiştirilmiş uzmanlar ile uygun ortamlarda sürdürülen eğitim olarak tanımlanmaktadır (MEB, 2018). Bu kapsamda özel eğitim hizmetleri denilince özel olarak yetişmiş eğitimciler, özel program içeriği, yöntem ve araçlar anlaşılmaktadır (Özyürek, 2019). Bu bilgiler doğrultusunda özel eğitimin süreç içerisindeki gelişimini görebilmek açısından Türkiye'deki serüvenine bakmakta fayda vardır.

Türkiye'de özel eğitim alanındaki çalışmalar ilk kez 1950'lerde, Mitat Enç'in öncü girişimiyle Gazi Eğitim Enstitüsü bünyesinde gerçekleşmiştir. Ama bu girişim, alanda özel eğitim öğretmenlerine yönelik talep yetersizliği, bürokratik nedenlerin eğitim politikalarıyla çatışması gibi nedenlerden dolayı, programın iki dönem mezun verdikten sonra kapatılması ile sonuçlanmıştır (Altunya, 2006; Akçamete, 1998; Özyürek, 2008). Daha sonra 1953-1980 yı1ları arasında özel eğitim öğretmeni ihtiyacı, hizmet içi eğitim programları ve sertifika programlarıyla karşılanmaya çalışılmıştır. Son olarak 1980 yılı itibariyle özel eğitim öğretmenliği programı sırasıyla Anadolu Üniversitesi, Gazi Üniversitesi ve Ankara Üniversitesi bünyesinde açılmıştır (Altunya, 2006; Çitil, 2009). Bu atılımlardan sonra özel eğitim öğretmenleri, lisans programlarıyla yetiştirilmeye başlanmıştır. Üniversitelerin verdiği mezunlar, sayıca özel eğitim alanındaki öğretmen ihtiyacını karşılamaya yetmemesi sebebiyle Millı̂ Eğitim Bakanlığı (MEB), farklı branşlardan öğretmenlere sunulan sertifika programları aracılığıyla Türkiye'de özel eğitim öğretmeni ihtiyacını karşılamaya çalışmaktadır (MEB, 2020).

MEB, özel eğitimdeki öğretmen açı̆̆ı problemine çözüm üretmek için 2014 yılından itibaren mezun olunan lisans programına bakılmaksızın zihin engelliler, görme engelliler, işitme engelliler ya da üstün zekâlılar öğretmenliğinden mezun olan öğretmenleri özel eğitim öğretmeni olarak atamıştır (MEB, 2018a). Yükseköğretim Kurulu (YÖK), 2015 yılında özel eğitim alanında öğretmen yetiştirme sorunlarının görüşülmesi amacıyla gerçekleştirdiği toplantıda özel eğitimin tek çatı altında birleştirilmesine karar vermiştir. Ülkedeki özel eğitim öğretmeni ihtiyacının her geçen gün artması ve hâlihazırdaki programın öğretmen niteliği ihtiyacını karşılayamaması sorunsalının bu kararı etkilediği söylenebilir. $\mathrm{Bu}$ karar 
doğrultusunda, 2016-2017 eğitim-öğretim y1lı itibariyle, özel eğitim dâhilindeki branşlar, "Özel Eğitim Öğretmenliği” adi altında birleştirilmiş ve program içeriği yeniden düzenlenmiştir (Büyükalan Filiz, Çelik Şahin, Tufan \& Karaahmetoğlu, 2018). Programın son güncellemesi ise 2018-2019 döneminde yapılmıştır (MEB, 2020a).

Bu araştırmada özel eğitim alanında görev yapan öğretmenlerin, Zihin Engelliler Öğretmenliği, Görme Engelliler Öğretmenliği, İşitme Engelliler Öğretmenliği ve Üstün Zekâlılar Öğretmenliği lisans programlarının "Özel Eğitim Öğretmenliği” lisans programı adı altında birleştirilmesine ilişkin görüşlerinin belirlenmesi amacıyla eski program mezunu özel eğitim öğretmenlerinin,

1. Mezun oldukları lisans programına yönelik düşünceleri nelerdir?

2. Zihin, işitme, görme engeliler, üstün zekalılar öğretmenliği lisans programlarının özel eğitim lisans programı olarak birleştirilmesine yönelik görüşleri nelerdir?

3. Özel eğitimde çalışırken karşılaştıkları sorunlar nelerdir?

4. Özel eğitim öğretmenliği lisans programının niteliğinin artırılmasına yönelik önerileri nelerdir? sorularına cevap aranmıştır.

$\mathrm{Bu}$ araştırma, üstün zekâlılar öğretmenliği mezunlarına ulaşılamadığı için Zihin Engelliler Öğretmenliği, Görme Engelliler Öğretmenliği, İşitme Engelliler Öğretmenliği lisans programlarından mezun olan öğretmen görüşleri ile sınırlandırılmıştır. Araştırma, 2016-2017 dönemi itibariyle yapılan program değişikliğinin öngörülen ihtiyaçları karşılayıp karşılayamadığının anlaşılması ve YÖK'ün, Eğitim Fakültelerine devrettiği program güncelleme çalışmalarına kaynaklık etmesi bakımından önem arz etmektedir.

\section{YÖNTEM}

\section{Araştırma Modeli}

Bu çalışma, nitel araştırma yöntemi ile gerçekleştirilmiştir. Nitel araştırmalarda gözlem, görüşme, doküman analizi gibi farklı kaynaklardan elde edilen veriler önce incelenerek kodlanır ve sonra kodlamalar dikkate alınarak sentezlenerek bulgulara ulaşılır (Büyüköztürk, Kılıç Çakmak, Akgün, Karadeniz \& Demirel, 2019).

\section{Katılımcılar}

Araştırmanın katılımcılarını farklı üniversitelerin zihin, işitme ve görme engelliler öğretmenliği mezunu olan ve Türkiye'nin farklı bölgelerinde görev yapmakta olan (Resmî / Özel) 55 özel eğitim öğretmeni oluşturmaktadır. Katılımcılar amaçlı örnekleme yöntemlerinden kolay ulaşılabilir durum örneklemesine göre oluşturulmuştur. $\mathrm{Bu}$ örnekleme yöntemi araştırmaya hız ve uygulanabilirlik katar; bu yöntemde araştırmacı, yakın olan ve erişilmesi kolay olan bir durumu seçer (Yıldırım \& Şimşek, 2011).

Araştırmaya katılan $n=53$ katılımcının \%53'ü $(n=28), \% 47$ 'si $(n=25)$ erkektir. Araştırmaya katılan öğretmenlerin \%67'si $(n=36)$ resmî kurumlarda, \%33’ü $(n=17)$ özel kurumlarda çalışmaktadır. Bu bilgiler 1şığında katılımcıların çoğunluğunun resmî kurumlarda çalışan öğretmenler olduğu söylenebilir. Katılımcıların \%45'i $(n=24)$ zihin engelliler öğretmenliği, $\% 51$ 'i $(n=27)$ işitme engelliler öğretmenliği, \%4'ü $(n=2)$ görme engelliler öğretmenliği mezunudur. Araştırmanın katılımcılarına ilişkin demografik özellikler Tablo 1'de verilmiştir. 
Tablo 1. Katılımcıların Demografik Özelliklerine Göre Dağılımı

\begin{tabular}{llll}
\hline Kategori & Sınıflama & N & $\%$ \\
\hline \multirow{2}{*}{ Cinsiyet } & Kadın & 28 & 53 \\
& Erkek & 25 & 47 \\
Çalı̧̧ılan Kurum & Resmî Kurum & 36 & 67 \\
& Özel Kurum & 17 & 33 \\
& Zihin Engelliler Öğretmenliği & 24 & 45 \\
Mezun Olunan & İsitme Engelliler Öğretmenliği & 27 & 51 \\
Program & Görme Engelliler Öğretmenliği & 2 & 4 \\
& & & \\
\hline
\end{tabular}

\section{Veri Toplama Araçlart}

Araştırmada veriler, yarı yapılandırılmış görüşme formu ile elde edilmiştir. Form oluşturma sürecinde öncelikle ilgili literatür taraması yapılmış bununla birlikte bir alan öğretmeni, bir eğitim programları ve öğretim ile bir özel eğitim alanında uzman akademisyenin görüşüne başvurulmuştur. Hazırlanan form mail yoluyla uzman akademisyenlerin incelemesine sunulmuş ve iki soru çıkarılmış, bir soruda düzeltmeye gidilmiştir. Formun ilk kısmı kişisel bilgi bölümünden oluşmakta olup "cinsiyet, mezun olunan program türü, çalış1lan kurum türü (özel, resmî)" gibi kapalı uçlu sorulardan oluşmaktadır. Formun ikinci kısmı eski özel eğitim lisans programının eksikleri, özel eğitim öğretmenlerinin çalışırken karşılaştığı sorunlara yönelik bulgular, 2016-2017 eğitim-öğretim yılı öncesinde yürürlükte olan eski lisans programının iyileştirilmesine yönelik öneriler üzerinden öğretmenlerin birleştirilmiş programa yönelik fikirlerinin alındığ 1 dört açık uçlu sorudan oluşmaktadır. Yarı yapılandırılmış görüşme formu Google.docs formatıyla katılımcılara ulaştırılmıştır.

\section{Verilerin Analizi}

Veriler nitel araştırma yöntemlerinden içerik analizi ile çözümlenmiştir. İçerik analizi, insan davranışları ve doğasını belirleme üzerinde doğrudan olmayan yollarla çalışmaya imkân tanıyan bir tekniktir (Büyüköztürk ve diğerleri, 2019: 259). Toplanan verilerin önce kavramsallaştırılması, daha sonra da ortaya çıkan kavramlara göre mantıklı bir biçimde düzenlenmesi ve buna göre veriyi açıklayan temaların saptanması gerekmektedir (Yıldırım \& Şimşek, 2011: 227). Bu bağlamda içerik analizinde araştırmacı, öncelikli olarak araştırma konusu ile ilgili kategoriler geliştirmektedir. Araştırmacı daha sonra incelemiş olduğu veri setinde, bu kategoriler içerisine giren kelime, cümleleri saymaktadır. Kategori geliştirme aşamasında araştırmacı dikkatli olmalı ve aynı metin üzerinden benzer bir araştırma yürütmeyi planlayan başka araştırmacıların da aynı sonuçlara ulaşabilecekleri türden uygun kategoriler geliştirmelidir (Özdemir, 2010). Benzer araştırmalar öncülünde ve bu bilgiler doğrultusunda araştırmada katılımcıların her bir soruya verdikleri yanıtlar, belirli temalar çerçevesinde bir araya getirilerek düzenlenmiş ve yorumlanmıştır.

Nitel araştırmalarda dış geçerliğin sağlanması için yapılan araştırmada katılımcı görüşlerine doğrudan yer verilir. İç geçerliğin sağlanması için kullanılan yöntemlerden biri 
"katılımcı teyidi" yöntemidir. Katılımcı teyidi kapsamında araştırmacı, katılımcılarla bireysel ya da grup olarak görüşerek araştırma sonuçlarını katılımcılarla paylaşır ve sonuçların geçerliğine ilişkin değerlendirme yapmalarını ister (Başkale, 2016; Özdemir, 2010; Yıldırım \& Şimşek, 2011). Geçerliğin, güvenirliği önemli ölçüde güvence altına aldığı düşünüldüğünde, geçerliğe verilen önem aynı zamanda güvenirliği sağlamaya yönelik alınmış bir önlem olarak algılanmalıdır (Yıldırım \& Şimşek, 2011: 274). Bu bağlamda araştırma kapsamında 15 katılımcı ile bireysel görüşmeler yapılmış, araştırma sonuçları paylaşılmış kendi görüş ve ifadelerine göre geçerliliği sorgulanarak tutarlı sonuçlara ulaşılmıştır. Dış geçerliğin sağlanması noktasında ise bulgular kısmında katılımcı görüşlerine doğrudan yer verilmiştir.

\section{BULGULAR}

\section{Katılımcıların Demografik Özelliklerine Yönelik Bulgular}

\section{Mezun Olunan Lisans Programına Yönelik Bulgular}

Görüşme formunda öğretmenlere "Mezun olduğunuz özel eğitim lisans programının eksiklerinin neler olduğunu düşünüyorsunuz?" sorusu yöneltilmiş alınan cevapların tematik sıklık değerleri Tablo 2'de verilmiştir.

Tablo 2. "Mezun olduğunuz özel eğitim lisans programının eksiklerinin neler olduğunu düşünüyorsunuz?" Sorusuna Yönelik Temalar ve Siklık Değerleri

\begin{tabular}{lll}
\hline Tema & $\mathrm{f}$ & $\%$ \\
\hline Uygulama Dersleri & 25 & 37 \\
Müfredat & 20 & 29 \\
Öğretim Elemanı Niteliği & 13 & 19 \\
Aile Eğitimi & 10 & 15 \\
\hline
\end{tabular}

Tablo 2'de temalara yönelik sıklık değerleri incelendiğinde lisans sürecinde uygulama derslerinin yetersizliğine yönelik ve müfredat içeriğinin yetersizliğine yönelik getirilen eleştirilerin çoğunluğu oluşturduğu görülmektedir. Bu temaları takiben öğretim elemanlarının donanım bakımından eksik olması ya da var olan programı uygulamada eksik kaldıklarını dile getiren katılımcı görüşlerinin ve programın aile eğitimine yönelik verilen eğitim açısından yetersiz kaldığına yönelik görüşlerin yer aldığı görülmektedir. Bu bağlamda bazı katılımcıların görüşleri şu şekildedir:

K54: "Teorinin uygulama ile pekiştirelememesi. Ne kadar kişisel girişimlerim doğrultusunda saha tecrübesi kazanmaya çalışsam da üniversiteler bu konuda yetersiz ve verimsiz. Akademik kadro alan uzmanlığına sahip kişilerden oluşmayabiliyor. Bunun yanı stra aile eğitimi teorik olarak verilse de uygulamada yetersiz."

K14: "Genel olarak uygulanacak yöntemin eksikliği. Davranışç yaklaşım temeli ă̆ırlıklı eğitim alıp farklı yaklaşımların detaylandırılmaması ve staj eksikliği."

K36: "Yeterince uygulamaya dönük olmamast ve otizmli bireylerin eğitimi noktasında daha nitelikli bir ě̆itim eksikliği."

K46: “Tüm alanlara yönelik bir ĕgitim verilememektedir. Öğretmen olarak yetersiz kaldığımı düşünüyorum." 
K55: "Aile ile iletişim ya da aile eğitimi nasıl yapılmalı konularında çok donanımlı mezun olmadık. Süreçte bunu tecrübe etmek yorucuydu. Teori ve uygulama uyuşmazlı̆̆l, uygulama eksikliği."

Görüşme formunda öğretmenlere "2016-2017 eğitim-öğretim y1lı itibariye yürürlüğe giren özel eğitim lisans programının içeriği hakkında bilgilerinin olup olmadığı sorulmuştur.

Tablo 3. 2016-2017 Eğitim-Öğretim Yılı Özel Eğitim Lisans Programının İçeriği Hakkındaki Bilgilere İlişkin Temalar ve Siklık Değerleri

\begin{tabular}{lll}
\hline Tema & $\mathrm{f}$ & $\%$ \\
\hline Evet & 3 & 6 \\
Kismen & 37 & 67 \\
Hayir & 15 & 27 \\
\hline
\end{tabular}

Tablo 3 incelendiğinde "Evet" cevabını veren 3 (\%6), "Kısmen" cevabı veren 37 (\%67) katılımc1 ve "Hayır" cevabı veren 15(\%27) katılımc1 olduğu görülmektedir. Cevaplar incelendiğinde, her üç tema altında görüş bildiren katılımcılarında genel olarak sadece programların tek çatı altında birleştirildiğini söylediği görülmektedir. Evet veya kısmen cevabını veren kimi katılımcılar ise detaylı incelemediklerini dile getirmişlerdir. Bu doğrultuda 2016-2017 eğitim-öğretim y1lı itibariye yürürlüğe giren özel eğitim lisans programına yönelik yeterli düzeyde bilgiye sahip olunmadığı görülmektedir. Bazı katılımcıların görüşleri şu şekildedir:

K6: "Klsmen. Özel eğitimdeki farklı branşlar birleştirilip tek bir branş haline getirildi."

K12: "Evet. Genel olarak var."

K18: "Hayır. Yeterli kadar yok."

K20: "Hayır içeriğini bilmiyorum. Özel Eğitim olarak tüm bölümler birleştirildi."

K36: "Evet alanlar özel ĕ̆itim öğretmenliği adı altında birleştirildi."

K53: "Kısmen. Programı detaylı incelemedim."

\section{Zihin, İşitme, Görme Engelliler, Üstün Zekâlılar Öğretmenliği Lisans Programlarının Özel Ĕgitim Lisans Programı Olarak Birleştirilmesine Yönelik Bulgular}

Görüşme formunda öğretmenlere "Zihin, işitme, görme engeliler, üstün zekalılar gibi özel eğitim programlarının özel eğitim lisans programı olarak birleştirilmesini uygun buluyor musunuz?" sorusu yöneltilmiş alınan cevaplar olumlu ve olumsuz olarak iki temada incelenmiştir.

Tablo 4. "Özel eğitim lisans programının tek programda birleştirilmesini uygun buluyor musunuz?" Sorusuna Yönelik Temalar ve Sıklık Değerleri

\begin{tabular}{lll}
\hline Tema & $\mathrm{f}$ & $\%$ \\
\hline Olumlu & 19 & 35 \\
Olumsuz & 36 & 65 \\
\hline
\end{tabular}


Tablo 4'te katılımcıların \%35'nin $(n=39)$ olumlu yanıt verdiği, \%65'inin $(n=36)$ olumsuz yanıt vermesinden programların birleştirilmesine yönelik olumsuz bir kanaatin olduğu anlaşılmaktadır. Bu bağlamda olumlu yönde görüş bildiren bazı katılımcıların görüşleri şu şekildedir:

K13: "Evet, çünkü çalışırken özel kurumları bu ayrıma pek fazla dikkat etmiyor. En azından bir öğretmenin her alanda giriş düzeyinde olsa bile belli bir birikime sahip olması gerekiyor."

K52: "Bir özel eğitimci bütün alanlarla ilgili bilgiye sahip olması gerektiğini düşünüyorum. Bu yüzden uygun buluyorum."

Olumsuz yönde görüş bildiren bazı katılımcıların görüşleri şu şekildedir:

K50: "Hayır. Teoride yeni program lisans sürecinde alan uzmanlığını öngörmektedir. Ama bildiğim kadarıyla üniversitelerin akademik personel çeşitliliğinin yetersizliğinden daha birçok teknik sebepten genel program daha çok zihin engeli, otizm, öğrenme güçlüğü alanlarında uzmanlaşmaya yöneliktir bu durum kısıtlayıcıdır."

K14: "Sadece zihin engelliler programında bile o kadar farklı engel grupları varken ve hepsi hakkında yeterli bilgi edinip mezun olamamışken daha çok alanla birleşmesini uygun bulmuyorum."

\section{4. Özel Ĕ̈itimde Çalışırken Karşılaşılan Sorunlara Yönelik Bulgular}

Görüşme formunda öğretmenlere Özel eğitimde çalışırken karşılaştığınız en önemli sorunlar nelerdir? sorusu yöneltilmiş alınan cevapların tematik sıklık değerleri Tablo 5'te verilmiştir.

Tablo 5. “Özel eğitimde çalışırken karşılaştı̆̆ınız en önemli sorunlar nelerdir?” Sorusuna Yönelik Temalar ve Sıklık Değerleri

\begin{tabular}{lcc}
\hline Tema & f & $\%$ \\
\hline Aile Eğitimi & 21 & 31 \\
Mesleki Yeterlilik & 11 & 16 \\
Kurum İdaresi & 11 & 16 \\
Kurumların Materyal, Fiziksel Donanımı & 11 & 16 \\
Branş Dışı Atama & 10 & 15 \\
$\begin{array}{l}\text { Rehberlik ve Araştırma Merkezlerinin } \\
\text { (RAM) İşlevselliği }\end{array}$ & 4 & 6 \\
\hline
\end{tabular}

Tablo 5 incelendiğinde katılımcıların, ailelerin eğitim yetersizliği sebebiyle karşılaştıkları iletişim sorunlarının çoğunlukta olduğu görülmektedir. Bu bulgu programda görülen aile eğitimi dersinin niteliksizliğini desteklemektedir. Mesleki yeterlilik, kurum idaresi ile yaşanılan sorunlar ile materyal ve fiziksel donanımın yetersizliğine yönelik sıklık değerlerinin aynı olduğu görülmektedir. Katılımc1 görüşleri neticesinde oluşturulan mesleki yeterlilik teması, bireysel eleştiriyle birlikte katılımcıların kimi meslektaşları adına getirdikleri eleştirileri 
kapsamaktadır. Bu temaları takiben Rehberlik ve Araştırma Merkezlerinin okullarla iş birliği içerisinde olmaması, lisans programlarını desteklemeyen değerlendirme ve yönlendirme çalışmalarına yönelik görüş sıklığı az olmakta beraber başka araştırmalara görüş sağlayabileceği düşüncesiyle değerlendirmeye alınmıştır. Bu bağlamda bazı katılımcıların görüşleri şu şekildedir:

K9: "Alan dışından mezun olmuş sertifikalı ögretmenlerin ögrencilerde sebep olduğu yıkımı düzeltmeye çalışmak."

K38: “Özel sektörün; tek bir alan ögretmeninin örneğin işitme engelliler öğretmeninin sanki dil terapisti, fizik tedavi uzmanı gibi performans göstermesini beklemesi ya da çocuk gelişimi uzmanına kendi alanı dışında vazifeler vermesi, özel ĕgitimli çocuğun velilerine alanında uzman öğretmenin gerekli gördüğ̈̈ yönlendirmeyi değil de kurumun çıkarlarına ve rahatına uygun dönütler vermeyi tercih etmesi beni son derece zorlayan ve üzen durumlardır Özel eğitimli çocuğun velilerine alanında uzman ögrretmenin gerekli gördüğ̈̈ yönlendirmeyi değil de kurumun çıkarlarına ve rahatına uygun dönütler verilmesinin tercih edilmesi beni son derece zorlayan ve üzen durumlardır."

K43: "Aile kaygısı, materyal yetersizliği, kurum içerisindeki genel fiziksel şartların yetersizliği ve eğitici personelin yeterince kendini güncellememesi."

K44: "Bazı veliler ile iş birliği tam anlamıyla sağlanamamakta. Öğrenciler için verilen $R A M$ raporunda doğru kararların verilmemesi nedeniyle ă̆ır düzeyde ögrenciler hafif düzey okuluna/sınıfina ya da tam tersi hafif düzey ögrenciler ă̆ır düzey okuluna/sınıfina yerleştiriliyor."

K53: "Aile bilinçsizliği ve aile ile iletişim kuramamak. Bilinçsiz meslektaşların varlı̆̆ sebebiyle öğrencilerin eğitiminin niteliksiz olması. Anlayışsız yönetim kadrosu benim dahilimde özel yahut MEB'de çalışan birçok meslektaşımın genel problemidir."

\section{5. Özel Ĕ̈itim Öğretmenliği Lisans Programının Niteliğinin Artırılmasına Yönelik Önerilerine Ait Bulgular}

Görüşme formunda öğretmenlere "Özel eğitim lisans programının niteliğinin artırılmasına yönelik önerileriniz nelerdir?" sorusu yöneltilmiş alınan cevaplar belirli temalar altında incelenmiş sıklık değerleri Tablo 6'da verilmiştir.

Tablo 6. "Özel eğitim öğretmenliği lisans programının niteliğinin artırılmasına yönelik önerileriniz nelerdir?" Sorusuna Yönelik Temalar ve Sıklık Değerleri

\begin{tabular}{lll}
\hline Tema & $\mathrm{f}$ & $\%$ \\
\hline Uygulama Dersleri & 50 & 58 \\
Müfredat Niteliği & 20 & 23 \\
Öğretim Elemanı Niteliği & 15 & 18 \\
Yüksek Lisans Şartı & 3 & 1 \\
\hline
\end{tabular}

Tablo 6 incelendiğinde katılımcıların çoğunluğunun uygulama derslerinin arttırılması ve derslerin çoğunlukla uygulamaya dönük olması gerektiği görüşünü bildirdikleri görülmektedir. Müfredat başlığı alan uzmanlığı, farklı engel gruplarını tanıma, aile eğitimi başlıklarını kapsamakta olup katılımcıların önemli bir kısmı bu başlıklara yönelik müfredatın yeniden düzenlenmesi gerektiği noktasında görüş bildirmiştir. Öğretmen yetiştirme programı için 
yüksek lisans şartına yönelik görüş sıklığı az olmakla birlikte araştırmanın kapsamına katkı sağladığından bununla birlikte başka araştırmalara görüş sağlayabileceği düşüncesiyle değerlendirmeye alınmıştır. Bu bağlamda bazı katılımcıların görüşleri şu şekildedir:

K14: "Daha çok staj sağlanmalı 2. Sinıftan itibaren aktif katılımlı stajlar uygulanmalı engel alanlarının tümüyle çalışmadan ögrenci mezun olmamalı ve olabildiğince farkl yaklaşım ögrenciye sunulmal ki mezun olduktan sonra ekstra sertifika programlarına gerek kalmasin."

K53: "Uygulama sürecinin daha erken dönemde başlatılmaslyla beraber niteliğinin de önemli olduğunu düşünüyorum. Öğrenci mezun olmadan çalışacă̆ engel grubuyla tanışmalı hatta hemen her engel grubuyla temasa geçmiş olması gerektiğini düşünüyorum. Tüm bunların yanında akademik kadronun kaliteli olması gerektiğini düşünüyorum."

K55: "Aile eğitimi konusunda gerçekçi uygulamalar yapılabilir lisansta. Alan uzmanlı̆̆l için sahada görevli ögretmenler ve önemli bilim insanlart ile buluşmalar gerçekleştirilebilir. Öğrenci ve yetersizlikten etkilenmiş birey teması erken dönemde başlatılıp ögrenciyi nelerin beklediği anlatılmalı. Çünkü bu meslek herkesin yapabileceği bir iş değil. Lisansa kabul edilen ögrenciler belirli nitelikler dâhilinde alınmalı."

K35: "Yüksek lisans şart olmal. Daha çok sahaya inilmeli, eksikler gözlenip, düzeltmeye yönelik ĕgitim verilmeli."

\section{TARTIŞMA VE SONUÇ}

$\mathrm{Bu}$ araştırmada özel eğitim öğretmenlerinin, mezun oldukları programların eksiklerinin neler olduğu yönündeki görüşlerinin belirlenmesi ve bu doğrultuda 2016-2017 Özel Eğitim Öğretmenliği Lisans Programının neleri karşılayıp karşılamadığının saptanması amaçlanmıştır. Bu amaçla öğretmenlere lisans dönemi ile öğretmenlik sürecinde karşılaştıkları sorunlar üzerine ve birleştirilmiş özel eğitim lisans programına yönelik açık uçlu sorular sorulmuş verilen cevaplar belirli temalar dâhilinde gruplandırılarak incelenmiştir. Elde edilen bulgular, bazı temel konularda öğretmenlerin yakın görüşte olduğunu göstermektedir.

Araştırma sonuçlarıyla eski programlara yönelik belirtilen görüşler temel olarak;

- Uygulama derslerinin yetersizliği ve niteliksiz olması

- Var olan ders programının nitelikli öğretmen ihtiyacını karşılayamaması (Farklı engel gruplarını tanıma, seçilen alanda uzmanlık vb)

- Güncellenen programın uygulamada başarılı olup olamayacağı sorunsalı

- Öğretim elemanı yetersizliği ve niteliksizliği

- Atama politikalarının öğretmen yetiştirme politikalarının önüne geçmesi

- Lisans programlarının kişisel gelişimi de destekler niteliğe sahip olmaması

başlıkları altında toplanabilir. Bu neticeyi destekler nitelikte Özyürek (2008), öğretmen yetiştirme sürecinde üç temel tehlikeyi öngörmüştür:

- Kısa süreli eğitim programlarıyla yetişmiş alan dışı öğretmenleri atama

- Yeterli öğretim elemanı ve alt yapı sağlanmadan özel eğitim bölümlerinin açılması

- Tepkisel ve popülist yaklaşımlarla öğretmen yetiştirme programlarını düzenleme

Aynı araştırmada kültürlü, meslek ve alan bilgisine sahip öğretmenler yetiştirmeyi amaçlayan programlar hazırlanırken süreçte görev alan kişilerin genellikle okul veya sınıflarda öğretim işiyle doğrudan ilgili kişiler olmadığının yanı sıra bu ortamlarda nadiren bulunan kişiler 
olduğunu belirtmektedir. Bununla birlikte meslekte yeterli bir öğretmenin yaptıklarını analiz ederek ya da öğretmenlerin sahadaki rolünü dikkate alarak programı nitelikli hale getirmenin öncelikleri arasında olmadığını; bu programların öğretmen adayına öğretmeyle ilgili becerileri kazandırmayı nadiren amaçlarken daha çok bilgi ağırlıklı oluğunu söylemektedir. Lisans sürecine getirilen bir başka eleştiri ise öğretim elemanlarının standartlardan uzak daha çok kendi değer yargılarına göre dersleri ve içerikleri belirlediği ders programlarının öğrenci için belirlenen süreci tamamlamaktan ibaret olduğu olumsuz bir ifadeyle vurgulanmaktadır.

$\mathrm{Bu}$ temellendirmenin yanı sıra alanyazında yer alan eski özel eğitim lisans programlarının niteliklerine yönelik yapılan bazı araştırma sonuçları ele alınmıştır. Literatürde temel eğitim ve diğer kademelerin eski lisans programları ve güncel lisans programlarının karşılaştırılmalı incelemesine yönelik kısıtlı çalışmaya ulaşılmıştır. Bu sebeple eski özel eğitim lisans programlarının niteliğine yönelik gerçekleştirilen araştırmalarla tartışma bölümü gerçekleştirilmiştir.

İlgili araştırmalarda eski özel eğitim lisans programlarının içerik yönünden öğretmen adaylarının ihtiyacına hizmet edip etmediği, müfredatın işlevselliği, akademisyenlerin niteliğí, uygulama derslerinin programdaki yerine yönelik bulgulara ulaşılmıştır. Bu hususta Karasu, Aykut ve Yılmaz'ın (2014) zihin engelliler öğretmenliği programında gerçekleştirilebilecek olası değişiklikler hakkında öğretmelerden görüş aldıkları çalışmanın sonucuna göre destekleyici derslerin açılması, seçmeli ders alternatiflerinin artırılması, ders içeriklerinin zenginleştirilmesi ve uygulama firsatlarının artırılması konularına odaklanıldığı görülmektedir. Görgen, Çokçalışkan ve Korkut (2012) ise öğretmen adaylarına mesleki beceri ve deneyimleri kazandırmayı amaçlayan öğretmenlik uygulaması dersinin derste görevli öğretim üyeleri, öğretmenler ve öğretmen adayları açısından işlevselliğini tespit etmek amacıyla bir araştırma yapmıştır. Araştırma sonucunda öğretmenlik uygulaması dersinin araştırmaya katılan öğretmen adaylarının sadece \%30'u tarafından öğretmenlik yeterliliklerini kazandırmada en etkili ders olarak görülmesine rağmen öğretmen adaylarının \%70'i diğer dersleri daha etkili görmektedir. Elde edilen sonuçlar 1şığında öğretmenlik uygulaması dersinin meslek yeterliliklerini kazandırma yolunda işlevselliğinin attırılması açısından; ders sürecine, öğretim üyesine, öğretmene ve öğretmen adayına yönelik önerilerde bulunulmuştur. Bu araştırmaların yanı sıra zihin engelliler öğretmenliği 3.- 4. sınıf öğrencileri ve mezunlarının kendi bölüm programları hakkındaki düşüncelerini araştırıldığı Dedeoğlu, Durali ve Kış’a (2004) ait çalışmada, lisans derslerinde uygulamaya yönelik ve eğitim fakültelerinin yeniden yapılandırılmasına yönelik gerekliliği ortaya konmuştur. Ergül, Baydık ve Demir (2013) tarafından yapılan çalışmada özel eğitim öğretmenlerinin ve öğretmen adaylarının; özel eğitim öğretmenliği lisans programlarına, alan yeterliklerine ve kendi mesleki yeterliliklerine ilişkin görüşleri incelenmiştir. Bulgulara göre hem öğretmenlerin hem de öğretmen adaylarının akademik becerilerin öğretimi, sınıf yönetimi, dil ve konuşma becerilerin kazandırılması ve otizm konularında kendilerini yetersiz buldukları görülmüştür. Katılımcılar özel eğitim programında yapılması gereken değişiklikler noktasında ise, öğretmenlik uygulamalarının artırılması ve derslerin uygulamaya dönük olması önerilerinde bulunmuştur. $\mathrm{Bu}$ araştırmada da öğretmenlerden programa yönelik öneriler istenmiş ve yapılan araştırmayı destekleyen benzer dönüşler alınmıştır.

Özel eğitim programlarının kişisel gelişim ve mesleki gelişim üzerindeki etkisini ölçmek amacıyla Bayrakdar, Vural ve Barut (2016) tarafından gerçekleştirilen çalışmada, özel eğitim öğretmen adaylarının öz yeterlik düzeyleri ile öğretmenlik mesleğine yönelik tutumları arasında orta düzeyde anlamlı bir ilişki bulunmuştur. $\mathrm{Bu}$ bağlamda Zihin Engelliler öğretmen adaylarının öz yeterlik algısının İşitme Engelliler öğretmen adaylarından daha yüksek olduğu yönündedir. Öksüz ve Coşkun'un (2012) da zihin engelliler öğretmen adayları ile yapmış 
olduğu bir diğer çalışmada da uygulama derslerinin öz yeterlilik algılarını geliştirdiği sonucuyla uygulama derslerinin gerekliliği ve önemi vurgulanmıştır. Uygulanan lisans programlarının ögretmen adayının tutumlarını ve mesleki becerileri kadar kişisel becerilerini (öz yeterlik, öz denetim, iletişim becerileri vb) de etkilediğini gösteren birçok araştırma mevcuttur. Araştırma kapsamında da kimi katılımcılar bu hususta görüş bildirmiştir.

Katılımcılar lisans döneminde uygulama yapılan okullar ve mezun olduktan sonra çalıştıkları kurumlara yönelik kurum yönetimi tavrının önemini, materyal ve fiziksel donanımın önemini, uygulama derslerinin verimliliğini vurgulayan görüşler sunmuşlardır. Bu hususta araştırma sonuçlarına katkı sağlayacak doğrultuda, zihin engelliler öğretmenliği adaylarının uygulamada karşılaştığ problemlere ilişkin görüşleri üzerine Alptekin ve Vural'ın (2016) gerçekleştirdiği araştırma farklı boyutlarda ele alınmıştır. Öğretmen adaylarının kendilerinden kaynaklı problemlere ilişkin görüşler; uygulama konularıyla ilgili bilgi eksikliği, sınıf yönetimi, okula uyum sağlama, rol karmaşası, zamanı iyi kullanamama, öğrenciler, okul yönetimi vb başlıklar altında toplanmıştır. Uygulama okullarında sınıfın öğretmenlerinden kaynaklanan problemlere ilişkin görüşleri, alan dışı öğretmenlerin bilgi düzeyi ve öğretmenlerin öğretmen adayına bakış açısının olumsuz olması başlıkları altında toplanmaktadır. Bir diğer çalışma olan Bural ve Avşaroğlu'nun (2012) özel eğitim öğretmenliği adayları ile yaptığı çalışmada bu araştırma sonuçları ile yakındır. Araştırma bulguları, lisans uygulama derslerinin nitelik yönünden yeterli olmadığı yönündedir.

Uygulama derslerinin niteliğine yönelik farklı görüşlere ulaşılan çalışmalarda da mevcuttur. Ergenekon, Özen ve Batu'nun (2008) Zihin Engelliler Öğretmenliği Adaylarının Öğretmenlik Uygulamasına İlişkin Görüş ve Önerilerinin Değerlendirilmesi adlı nitel çalışmasında daha olumlu görüşler belirtilmiştir. Katılımcıların çoğunluğu uygulama programının beklentileriyle örtüştüğünü belirtmişlerdir. Öğretmen adaylarının yarısı, uygulama öğretim elemanlarından aldıkları dönütlerin yeterli olduğunu, diğer yarısı ise yeterli olmadığını dile getirmişlerdir.

Araştırma bulguları ve literatürde yer alan çalışmaların incelenmesi neticesinde araştırmanın temel amacı olan birleştirilen programların belirlenen eksiklikleri karşıllayıp karşılayamaması problemi teoride bir cevaba ulaştığı söylenebilir. Şöyle ki birleştirilmiş programda ikinci sınıfta gözlem, üçüncü sınıfta kurum deneyimi ve dördüncü sınıfta öğretmenlik uygulamasının yer alması dile getirilen uygulama eksikliğini karşılamaktadır. Lisans sürecinde farklı engel grupları hakkında bilgilendirilme ve farklı engel gruplarıyla temasa geçme noktasında görülen eksiklik, birleştirilmiş programda giderildiği söylenebilir. Bunun göstergesi ise yenilenen ders programı ve her uygulama aşamasının farklı bir kurumda yapılmasıdır. Bunun yanı sıra birleştirilmiş programın seçmeli ders düzenlemesiyle öğretmen adayının istediği alanda uzmanlaşmasının yolunun açıldığı söylenebilir.

Programın etkililiğinin sağlanabilmesindeki dikkat edilmesi gereken husus akademik kadro donanımı ve üniversite altyapılarının yeterliliğidir. Bu hususta öğretim üyelerinin birleştirilmiş program üzerine değerlendirme ve görüşlerinin araştırıldığı bir çalışmada; öğretim üyeleri eski lisans programlarının eksikliklerine yönelik en fazla uygulamalı dersler, atama ilkeleri, müfredat ve nitelik konularına değinmiştir. Birleştirilmiş özel eğitim lisans programının atama ilkeleri ve müfredat konularında bazı eksiklikleri giderdiği ancak, bu programın da öğretim elemanı yetersizliği, içeriğin belirsiz olması, nitelik kaygısı ve alt yap1 konularında eksikliklerinin olduğu üzerinde durulmuştur. Öğretim üyelerinin birleştirilmiş programa ilişkin en fazla öneride bulundukları konuların öğretim elemanı yetiştirme, iş birliği yapma, alt yapıyı geliştirme ve uzmanlaşmaya ilişkin olduğu görülmüştür (Büyükalan Filiz ve diğerleri, 2018). 
Araştırma bulgularının çoğunda değinilmeyen bir husus vardır. Lisansta eğitim süreci öğretim elemanın sunduğu bilgiden, saha tecrübesinden ibaret olmayıp öğretmen adayının kişisel becerileri (öz yeterlik, öz denetim, iletişim becerileri vb) de, merakını da kapsayan bir süreçtir. $\mathrm{Bu}$ sebeple her öğretmen yetiştirme programında olması gerektiği gibi alan uzmanlığının yanı sıra düşünme becerilerinin geliştirilmesi, öğrenmeyi öğrenme/öğretme becerileri, yetişkin eğitimi, teknoloji okur-yazarlığı vb yetkinlik alanlarının her öğretmen adayında bulunması gerektiği söylenebilir. Birleştirilmiş program incelendiğinde sunulan ders içeriklerinin bu becerileri karşılaması ön koşul olarak sunulmuştur. Bu bağlamda bünyesinde özel eğitim öğretmenliği programı hizmeti veren üniversitelerin, birleştirilmiş programın niteliklerinin ne kadarını karşılayabildiği; öğretim elemanlarının ön görülen seçmeli dersler konusunda, yukarıda belirtilen beceri alanlarında ne kadar yetkin olabildiği sorulması gereken sorulardır. Bu soruların cevabının genellenebilir olması eğitimin niteliği açısından önemli önemlidir.

Sonuç olarak birleştirilmiş program, literatür ve öğrenci, öğretmen akademisyenlerden alınan görüşler birlikte incelendiğinde ortaya konmuş olan ortak görüşlerin bu araştırma sonuçlarını destekler nitelikte olduğu görülmektedir. Bu karşılaştırma eski programların temel eksikliğinin ne olduğunu bizlere göstermektedir. 2016-2017 eğitim-öğretim y1lı itibariye yürürlüğe giren birleştirilmiş programın teorik bağlamda bu istekleri karşıladığı söylenebilir. Lakin Aygören ve Er'in (2018) aktarımıyla Posner'in resmi program ve uygulanan program arasında kurduğu ilişki referans alındığında birleştirilmiş programın uygulamada başarılı olup olmadığı sorunsalı devam edecektir. Bu sebeple birleştirilmiş program mezunu kitle ile bir çalışma yapılmadan, programa dair nitelikli bir sonuca ulaşılamayacağını belirtmekte fayda vardır. Bu bağlamda birleştirilmiş programdan henüz mezun olacak kitle ile de benzer bir çalışmanın yapılması, programın uygulamaya yansımalarını inceleyebilmek açısından önem arz etmektedir. Böyle bir çalışma ile bu araştırmadan elde edilen bulgular karşılaştırılıp, programın işleyişine yönelik daha kapsamlı bir görüşe varılabilir.

\section{KAYNAKÇA}

Akçamete, G. (1998). Türkiye'de özel eğitim. İçinde: Süleyman E. (Ed.), Özel eğitim (197-207). Eskişehir: Anadolu Üniversitesi Yayınları.

Alptekin, S. \& Vural, M. (2014). Zihin engelliler öğretmenliği adaylarının uygulamada karşılaştığı problemlere ilişkin görüş ve önerileri. International Periodical for The Languages, Literature and History of Turkish or Turkic, 9(2), 127-139.

Altunya, N. (2006). Gazi Eğitim Enstitüsü: Gazi Orta Öğretmen Okulu ve Eğitim Enstitüsü (19261980). Ankara: Gazi Üniversitesi.

Ataman, A. (2005). Özel gereksinimli çocuklar ve özel eğitim: özel gereksinimli çocuklar ve özel ĕ̆itime giriş. Ankara: Gündüz Eğitim ve Yayıncılık.

Aygören F. \& Er, K. O. (2018). Eğitimde program değerlendirme sinıflamalar-modeller. Ankara: Pegem Akademi Yayıncılık.

Aytaç, A. (2010). Öğretmenlik uygulaması dersi kapsamında uygulama öğretim elemanlığının değerlendirilmesi. Yayımlanmamış Yüksek Lisans Tezi. Mehmet Akif Ersoy Üniversitesi Sosyal Bilimler Enstitüsü, Burdur.

Başkale, H. (2016). Nitel araştırmalarda geçerlik, güvenirlik ve örneklem büyüklüğünün belirlenmesi. Dokuz Eylül Üniversitesi Hemşirelik Fakültesi Elektronik Dergisi, 9(1), 23-28.

Bayrakdar, U., Vural Batık M. \& Barut, Y. (2016). Özel eğitim öğretmen adaylarının öğretmen öz yeterlik düzeyleri ve öğretmenlik mesleğine yönelik tutumları. Ahi Evran Üniversitesi Kırşehir Eğitim Fakültesi Dergisi, 17(2), 133-149.

Büyükalan Filiz, S., Çelik Şahin A., Tufan, S. \& Karaahmetoğlu, B. (2018). Özel eğitim öğretmenliği lisans programlarının birleştirilmesine ilişkin öğretim üyelerinin görüşleri. Hacettepe Üniversitesi Eğitim Fakültesi Dergisi, 33(3), 763-775. 
Büyüköztürk Ş., K1lıç Çakmak, E., Akgün, Ö.E., Karadeniz Ş. \& Demirel F. (2019). Bilimsel araştırma yöntemleri. Ankara: Pegem Akademi.

Çitil, M., Karakoç, T. \& Küçüközyiğit, M. S. (2018). Özel eğitim lisans dersinin öğretmen adaylarının bilgi düzeylerine ve engellilere yönelik tutumlarına etkisi. Abant İzzet Baysal Üniversitesi Eğitim Fakültesi Dergisi, 18(2), 815-833

Dedeoğlu, S., Durali, S. \& Kış, A. T. (2004). Özel eğitim bölümü zihin engelliler öğretmenliği ana bilim dalı 3-4. sınıf öğrencileri ve mezunlarının kendi bölüm programları, öğretmen yetiştirme ve eğitim fakülteleri ile ilgili düşünce ve önerileri. Ankara Üniversitesi Eğitim Bilimleri Fakültesi Özel Ĕ̈itim Dergisi, 5(1), 47-55.

Erdem, A.R. (2012). Öğretmen yetiştirme programlarındaki alan ve alan eğitimi derslerinin yeniden düzenlenmesi gerekliliği. Pamukkale Üniversitesi Ĕ̈itim Fakültesi Dergisi, 1(31), 219-223.

Ergenekon, Y., Özen, A. \& Batu, E. S. (2008). Zihin engelliler öğretmenliği adaylarının öğretmenlik uygulamasına ilişkin görüş ve önerilerinin değerlendirilmesi. Kuram ve Uygulamada Eğitim Bilimleri, 8(3), 857-891.

Ergül, C., Baydık, B. \& Demir, Ş. (2013). Özel eğitim öğretmen adaylarının ve öğretmenlerinin zihin engelliler öğretmenliği lisans programı yeterliklerine ilişkin görüşleri. Kuram ve Uygulamada Ĕ̈itim Bilimleri, 13(1), 499- 522.

Görgen, İ., Çokçalışkan, H. \& Korkut, Ü. (2012). Öğretmenlik uygulaması dersinin öğretmen adayları, uygulama öğretmenleri ve uygulama öğretim üyeleri açısından işlevselliği. Muğla Üniversitesi Sosyal Bilimler Enstitüsü Dergisi, 28, 56-73.

Gürgür, H. (2013). İşitme engelliler öğretmenliği programında öğretmen eğitimcisi olarak yetişme sürecine eleştirel bakış: Öz değerlendirme araştırılması. Eğitimde Nitel Araştırmalar DergisiJournal of Qualitative Researchin Education, 1(1), 62-87.

Karasu, N. Aykut, Ç. \& Yılmaz, B. (2014). Zihin engellilerin eğitimi anabilim dalı öğretmen yetiştirme programı üzerine öğretmen görüşlerinin incelenmesi. Hacettepe Üniversitesi Eğitim Fakültesi Dergisi, 29(4), 129-142.

Kaya, E. (2013). Özel eğitim kurumlarında görev yapan meslek dersi ögretmenlerinin yeterlilikleri: Özel eğitim uygulama merkezi, iş uygulama merkezi, mesleki ĕgitim merkezi. Yayımlanmamış Yüksek Lisans Tezi. Yeditepe Üniversitesi Sosyal Bilimler Enstitüsü, İstanbul.

Kirk, S., Gallagher, J. \& Coleman, M. R. (2017). Özel gereksinimli çocukların eğitimi. (Çev. Ed. Rakap, S. ve Kalkan, S.). Ankara: Nobel Yayıncilik.

MEB (2018). Özel eğitim hizmetleri yönetmeliği. 25 Mayıs 2020 tarihinde https://orgm.meb.gov.tr/meb_iys_dosyalar/2018_07/09101900_ozel_egitim_hizmetleri_yonetmel igi_07072018.pdf adresinden erişilmiştir.

MEB (2018a). Millî Eğitim İstatistikleri Örgün Eğitim. 25 Mayıs 2020 tarihinde http://sgb.meb.gov.tr/meb iys dosyalar/2019 09/30102730 meb istatistikleri orgun egitim 20 18 2019.pdf. adresinden erişilmiştir.

MEB (2020, 2020a). 25 Mayıs 2020 tarihinde https://orgm.meb.gov.tr/. adresinden erişilmiştir.

Ögülmüş, K. (2014). Alan mezunu ve alan dışı lisans programlarından mezun özel eğitim ögretmenlerinin mesleki yeterliklerinin değerlendirilmesi. Yayımlanmamış Yüksek Lisans Tezi. Necmettin Erbakan Üniversitesi Eğitim Bilimleri Enstitüsü, Konya.

Öksüz, Y. \& Coşkun, K. (2012). Öğretmenlik uygulaması I-II derslerinin zihin engelliler öğretmen adaylarının öz-yeterlilik algılamaları üzerindeki etkisi. Ahi Evran Üniversitesi Kırşehir Ĕ̈itim Fakültesi Dergisi, 13(2), 131-155.

Özdemir, M. (2010). Nitel veri analizi: Sosyal bilimlerde yöntembilim sorunsalı üzerine bir çalışma. Eskişehir Osmangazi Üniversitesi Sosyal Bilimler Dergisi, 11(1), 323-343.

Özsoy, Y., Özyürek, M. \& Eripek S. (1989). Özel eğitime muhtaç çocuklar. Ankara: Karatepe Yayınları.

Özyürek, M. (2008). Nitelikli öğretmen yetiştirmede sorunlar ve çözümler: Özel eğitim örneği. Türk Ĕgitim Bilimleri Dergisi, 6(2), 189-226.

Özyürek, M. (2019). Özel eğitime muhtaç çocuklar ve eğitimleri. Ankara University Journal of Faculty of Educational Sciences (JFES), 16 (1), 17-26. DOI: 10.1501/Egifak_0000000949

Sezgin, O. (2013). Eğitimde psikolojik açıdan normale duyulan ihtiyaç, normalin ölçüsü ve çeşitleri. Kalem Uluslararası Ë̆itim ve İnsan Bilimleri Dergisi, 3(2), 241- 258. 
Tursun, A. (2019). 540 saatlik özel eğitim sertifika programıla alan değiştiren sınıf öğretmenlerinin özel eğitimde yeterlikleri hakkındaki görüşlerinin değerlendirilmesi. Yayımlanmamış Yüksek Lisans Tezi. Abant İzzet Baysal Üniversitesi Eğitim Bilimleri Enstitüsü, Bolu.

Ulay, G. (2018). Özel ĕgitim öğretmenliği lisans programının zihin engelliler öğretmenliği yeterlikleri açısından incelenmesi: Sakarya ili örneği. Yayımlanmamış Yüksek Lisans Tezi. Sakarya Üniversitesi Eğitim Bilimleri Üniversitesi, Sakarya.

Ünsal, H. (2001). Eğitim ve fen-edebiyat fakültelerinde uygulanmakta olan yeni ögretmen yetistirme modelinin fakülte ve bölüm değişkenlerine göre incelenmesi. Yayımlanmamış Yüksek Lisans Tezi. Gazi Üniversitesi Eğitim Bilimleri Enstitüsü, Ankara.

Varış, F. (1987). Eğitim bilimine giriş. Eskişehir: Anadolu Üniversitesi Açıköğretim Fakültesi Yayınları.

Yıldırım, A. \& Şimşek, H. (2011). Sosyal bilimlerde nitel araştırma yöntemleri. Ankara: Seçkin Yayıncilik.

\section{Kaynak Gösterimi İçin (For Cited In):}

Aydın, G. N. \& Şentürk, Ş. (2021). Özel eğitim bölümü lisans programlarının birleştirilmesine yönelik özel eğitim öğretmenlerinin görüşlerinin değerlendirilmesi. Turkish Journal of Primary Education (TUJPED), 6 (1), 36-50. doi: 10.52797/tujped.829099

\section{EXTENTED ABSTRACT}

\section{Introduction}

Every child is different a world and each of them are different children of worlds. Therefore, their mental, social and emotional developments, their learning speed and styles are different from each other. These differences occur so intensely in children with special needs that they need either a change in school practice or special education services to develop their unique abilities (Kirk, Gallagher, \& Coleman, 2017). When it comes to special education services, especially trained educators, special program content, methods and tools are understood (Özyürek, 2019). In this context, many methods have been applied in order to find a solution to the problem of teacher shortage in special education. As of the 2016-2017 academic year; The undergraduate programs of Teaching for the Mentally Impaired, Teaching for the Visually Impaired, Teaching for the Hearing Impaired and Teaching for the Gifted were combined under the name of "Special Education Teaching" undergraduate program and the content of the program was rearranged (Büyükalan Filiz, Çelik Şahin, Tufan, \& Karaahmetoğlu, 2018; MEB, 2018a). In this study; it was aimed to determine the opinions of special education teachers on what the deficiencies of the program they graduated from and accordingly, to determine what the Special Education Teaching Undergraduate Program (the combined program), which entered into force as of the 2016-2017 academic year. This research is important because it is known whether the program change made as of 2016-2017 meets the needs or not. However, no opinion was obtained from the graduates of the gifted teacher education.

\section{Method}

This research was carried out with qualitative research method. The participants of the study consist of 55 special education teachers who graduated from different universities' teaching for the mentally, hearing and visually impaired and working in different regions of Turkey. Participants were formed according to easily accessible situation sampling, one of the 
purposeful sampling methods. The data in the study were obtained using a semi-structured interview form. During the form creation process, the relevant literature was searched first, and the opinion of a field teacher and an expert in the field of Education Programs and Instruction was consulted. The prepared form was submitted to the expert academician via e-mail and two questions were drawn and one was corrected. The first part of the form consists of a personal information part. The second part of the form consists of open-ended questions. The semistructured interview form was delivered to the relevant people in the Google documents format. The data were analysed by content analysis. In the study, the answers given by the participants to each question were brought together within the framework of certain themes, arranged and interpreted. Participant opinions made to ensure external validity were directly included. The "participant confirmation" method was used to ensure internal validity. Within the scope of the research, individual interviews were made with 15 participants and consistent results were obtained.

\section{Findings}

Of the 53 participants participating in the research; 53\% $(n=28), 47 \%(n=25)$ of them are male. The teachers participating in the research; $67 \%(n=36)$ of them work in official institutions, $33 \%(n=17)$ of them work in private institutions. In the light of this information, it can be said that most of the participants are teachers working in official institutions. Participants; $45 \%(n=24)$ were graduates of teachers of the mentally handicapped, $51 \%(n=$ $27)$ of teachers for the hearing impaired, and $4 \%(n=2)$ of teachers for the visually impaired. Open-ended questions were asked to the teachers about the problems they encountered in the undergraduate period and the teaching process and the combined special education undergraduate program, and the answers were grouped under certain themes and analysed. The findings show that teachers are close to some basic issues: Insufficiency and unqualified practice courses; The existing curriculum does not meet the need for qualified teachers (recognizing different disability groups, expertise in the chosen field, etc.); Whether the updated program will be successful in implementation is the question; Insufficiency of teaching staff and inadequacy of teaching staff; Policies of appointment to take precedence over teacher training policies; Undergraduate programs do not support personal development.

\section{Conclusion}

When the combined program is examined and in parallel with the literature, it is seen that the opinions of students, teachers and academicians support the results of this research. This comparison shows us what is the main shortcoming of old programs. It can be said that the combined program, which entered into force as of the 2016-2017 academic year, theoretically meets these demands. Considering the relationship that Posner established between the official program and the implemented program, the problem of whether the combined program is successful in implementation will continue. Therefore; It can be said that a qualified result regarding the program cannot be achieved without conducting a study with the group graduates of the combined program. In this context; It is important to carry out a similar study with the audience who will just graduate from the combined program in order to examine the reflections of the program on the application. By comparing such a study and the findings obtained from this study, a more comprehensive view can be reached about the functioning of the program. 